\title{
Accounting Aspects of Reporting Business Relationships between Public Enterprises and Municipalities in Slovenia, Individual Comparisons with Italy and Austria, and International Guidelines
}

\author{
AleŠ NovaK, MAJDA KOKOTEC-NOVAK \& NIVES HALUŽAN
}

\begin{abstract}
Adequate accounting information is the foundation of an efficient public sector. As of 2010, the accounting aspect of business relationships between public enterprises and municipalities in Slovenia had to be redefined due to the abandonment of 'assets under management' reporting. The regulation recommending municipalities to hand over infrastructure to public enterprises in the form of an operating lease has resulted in the need for different accounting information on the part of the municipalities. Regarding the water sector of municipalities in Austria and Italy, the need for more comprehensive accounting information exists as well. Due to the application of New Public Management concepts, many countries have adopted or committed to adopt some variant of accrual accounting also for the public sector. The large-scale adoption of the International Public Sector Accounting Standards (the IPSASs) would significantly enhance the international public sector comparability.
\end{abstract}

KEYwORDS: • accrual basis accounting • cash basis accounting • municipality $\bullet$ public enterprise $\bullet$ Slovenia $\bullet$ Italy $\bullet$ Austria

CorReSPONDENCE ADDRESS: Aleš Novak, Ph. D., University of Maribor, Faculty of Organisational Sciences, Kidričeva cesta 55a, 4000 Kranj, Slovenia, email: ales.novak@fov.uni-mb.si. Majda Kokotec-Novak, Ph. D., University of Maribor, Faculty of Economics and Business, Razlagova 14, 2000 Maribor, Slovenia, email: majda.novak@uni-mb.si. Nives Halužan, Public Utility Company Žalec, Nade Cilenšek 5, 3310 Žalec, Slovenia, email: nives.haluzan@jkp-zalec.si.

DOI 10.4335/8.3.265-291(2010)

ISSN 1581-5374 Print/1855-363X Online (C) 2010 Lex localis (Maribor, Graz, Trieste, Split)

Avaliable at http://pub.lex-localis.info. 


\section{Introduction}

The public sector, which includes both public enterprises and municipalities, is linked with other segments of society in various ways. An efficient and wellorganised public sector is in the interest of the entire society, especially in times of financial crisis. The governments of individual countries seek different strategies for overcoming the crisis, and in these strategies, emphasis is also placed on the public sector efficiency. The expanding globalisation process puts the countries into an entirely new role. The old and emphatically regulatory role of the state is being replaced by a new partner role in which the state acts as an equal partner in other social subsystems in facilitating the successful development of the entire social system.

Despite the existing differences between various countries and groups of countries, there are prevailing global trends for adapting public sector operations to the private sector rules. In similar trends in state administration, changes are directed to an increased role of management in administration, to increasing efficiency, as well as to the results and clients.

Regardless of the numerous problems and specifics in measuring public sector efficiency, the adequate accounting information that reports the value aspect of business operations is quite important. In order to increase public sector efficiency and transparency, the New Public Management (hereinafter referred to as NPM), the public sector reform model, which privileges quantification and results, and in which accounting has a central role, is gaining in importance.

This paper concentrates on financial reporting of business relationships within a segment of the public sector, i.e., reporting of business relationships between local self-government (municipalities) and public enterprises. We place emphasis on the analysis of business relationships by reporting from the accounting perspective in Slovenia. In addition, we make certain comparisons with Italy and Austria in the respective field of research by looking at the case of the water sector. In particular, we point out financial reporting guidelines in the public sector at the international level.

\section{Fundamental Characteristics of Relationships between Public Enterprises and Municipalities}

The subject of our study is reporting of business relationships in the public sector ${ }^{1}$, i.e., between public utilities (where we concentrate on public enterprises) and local self-government. A public utility is a legal regime that is defined by the relationship between the public utility operators and the state or municipality. The users are the third element in this triangle relationship (Ferfila et al., 2002: 153). 
The Public Utilities Act ${ }^{2}$ of the Republic of Slovenia stipulates that public utilities provide public goods as either products or services. The Republic of Slovenia, a municipality or any other local community guarantee a permanent and undisturbed production or rendering of these goods or services in public interest in order to meet public needs when and to the extent to which they cannot be provided in the market.

In compliance with this Act, a public enterprise is defined as a form of implementing public utility activities. A public enterprise does not have its own legal organisational form. The provisions that define corporate entities determine it. In 2007, Slovenia adopted the Transparency of Financial Relations and Maintenance of Separate Accounts for Different Activities $\mathrm{Act}^{3}$ in compliance with Commission Directive 2006/111/EC. This Act stipulates that a public enterprise is any company on which public authorities (i.e., state authorities, municipal authorities) may exercise a dominant influence. This definition represents a change in the comprehension of a public enterprise. Brezovnik (2009: 182-183) analyses the issues related to the legal regulation of public enterprises in Slovenia.

In the past, there was a tradition of monopolised state-owned public enterprises in Europe. The states provided all public goods and services through their institutions, and restricted any competition. However, the technological, political and economic changes have been encouraging the liberalisation of public utilities ${ }^{4}$.

In order to enhance the performance of public enterprises and their commercialisation, the European countries have adopted the following measures: privatisation, concessions, compulsory competitive tendering, infrastructure commercialisation, private sector co-management, and the remuneration of managers in public utilities (Setnikar Cankar et al., 2008: 91).

In 2006, Slovenia adopted the Public-Private Partnership Act ${ }^{5}$ that complies with Commission Directives 2004/17/EC, 2004/18/EC, and 2005/51/EC. A publicprivate partnership thus represents a relationship involving private investment in public projects and/or public co-financing of private projects that are in public interest.

The inclusion of the private sector into the public interest projects may have its disadvantages, too. The private sector co-operates with the public sector for profit, which frequently collides with the public interest. Regardless of the drawbacks of such connections, we may ascertain that the inclusion of private capital is necessary. Moreover, the areas in which the public sector connects with the private sector are broadening (Kranjc, 2009: 199). 
Local self-government means exercising the rights of the population of a certain area to participate in decision-making on the matters of local importance. In compliance with the Local Self-Government Act ${ }^{6}$, municipalities are the basic self-governing local communities ${ }^{7}$. In accordance with laws, a municipality may possess, acquire or have at its disposal all types of assets, it may establish and manage public enterprises, and determine its budget within the system of public finances.

\section{Accounting Aspects of Reporting Business Relationships between Public Enterprises and Municipalities}

\subsection{Characteristics of Accounting and Public Sector Accounting}

Since we discuss the reporting business relationships, our research is directed towards the information ${ }^{8}$ on those economic categories that appear in business relationships between public utilities and local self-government.

We could say that accounting is a service activity. Its function is to provide quantitative information about economic entities. The information is primarily financial in nature and is used in making economic decisions by using reason in making choices between alternative courses of action (Alexander and Nobes, 2001: 4). Thus, accounting is a means to assist a wide variety of parties in making economic decisions. Accounting may be further divided into financial accounting and management or managerial accounting. Financial accounting is the branch of accounting that provides economic and financial information for external decision makers such as investors, creditors (bankers, bondholders, suppliers), and other third parties who have no ready access to an entity's financial records or accountants. Management accounting, on the other hand, is a branch of accounting that provides economic and financial information for decision makers inside the reporting entity such as managers, employees, and other internal users (Aleksander and Nobes, 2001: 4-5; Atkinson et al., 2003: 5; Kieso et al., 2005: 2) ${ }^{9}$. Apart from financial and management/managerial accounting, the accounting theory differentiates also between cost accounting (whose purpose is mainly to monitor and assess internal business operations) and financial accounting that summarises the results of cost accounting (Turk et al., 2004: 25-27).

In the setting of accounting theory, the discussion of accounting usually revolves around financial accounting and financial reporting. The former relates to the generation of accounting data for external reporting, while the latter is the communication of this data to interested parties outside the reporting entity ${ }^{10}$ (Higson, 2003: 19). Financial statements are the principal means of communication of financial information to external decision makers (Raiborn \& Watson, 2003: 7). 
Financial reporting differences arise due to the differences between financial reporting regulations and the differences in the ways in which the financial reporting regulations are interpreted or implemented, and due to the differences in the preferred practices (Roberts et al., 2002: 59).

We shall now focus on the system of external financial reporting from the viewpoint of a public utility, i.e., a public enterprise, as well as from the viewpoint of local self-government, i.e., a municipality, because accounting information reflects business relationships between public enterprises and municipalities. In addition, we shall point out the problems that occur in relation to the information for internal users.

Given that the focus of our research is the public sector, we must also discuss the public sector performance measurement. A successful state administration body must be efficient in implementing its services, must use work and other production factors efficiently, and the processes in which employees turn inputs into outputs must be of good quality. Only in this way can optimal results be achieved.

As regards public sector management, the concept of New Public Management (hereinafter referred to as NPM) is gaining in importance. The term NPM was coined because some generic label seemed to be needed for a general, though certainly not universal, shift in public management styles (Hood, 1995: 94).

The NPM is a model of the public sector reform that privileges quantification and results where accounting has a central role. It is a model in which mimicry of private sector practices is advocated (Lapesly et al., 2009: 720). It includes the replacement of input control by output control, management by result, assigning of responsibilities, and introducing private sector management techniques ${ }^{11}$ (Hood, 1995; in Christiaens, 2004: 744).

However, the NPM has also faced some criticism; namely, it is argued that it is founded on excessive similarities between public and private sectors. It must also be noted that the state holds a monopoly that originates in its legislative power, and that it has to act for the common good (Thom and Ritz, 2008: 24-33; Werner et al., 2006: 95-119).

All these aspects need to be considered within the research in the area mentioned above from the accounting viewpoint. The mode of reporting business events is a significant element that seems to be a difference in regulating the accounting of public enterprises and local self-government, i.e., municipalities. 
In theory, the following approaches to dealing with business events are possible (Kokotec-Novak, 1998: 328):

- Cash-basis accounting,

- full accrual basis of accounting, and

- modified cash-basis accounting and modified accrual basis of accounting.

Cash-basis accounting is accounting based on the cash concept where transactions are recorded on the date of cash receipts and payouts. Under cash-basis accounting, revenue is recorded when cash is received. Moreover, an expense is recorded when cash is paid. Under this system, there is no accounting for debtors, prepayments, creditors, inventories, and fixed assets (Weygandt et al., 2008: 90). This type of reporting is mainly used in state budget organisations, i.e., in the public sector.

According to the cash-basis accounting principles, the budget organisations must report cash flows of individual budget items and establish budget deficits and surpluses by taking into account budget-related legislation (Rau, 1994: 305-306). This system of accounting is also known as cameralistic accounting ${ }^{12}$.

Under full accrual basis of accounting, transactions are recorded in the periods in which the events occur. Revenue is recognised when it is earned, and expenses are recognised when they are incurred, regardless of the time of cash receipts or cash payments (Weygandt et al., 2008: 90). Such reporting of business events is typical of companies, i.e., of the private sector.

Modified cash-basis accounting ${ }^{13}$ and modified accrual basis of accounting for financial reporting can lean towards either of the above-discussed approaches. These modified approaches often include the model in which accounting statements include the cash flows of the time period in question, cash balance as well as receivables, tangible assets and liabilities (Antunović et al., 1994: 17-19).

A major implication of NPM has been an increased emphasis on 'management' rather than on 'administration of services', which entails the shift from the traditional stewardship role of accounting to cost management, and consequently accrual accounting. This shift in emphasis has brought the notion of value-formoney $^{14}$ supported by performance measurement, budgeting and costing techniques $^{15}$ (Jackson and Lapsley, 2003: 365-370). Full accrual accounting is proposed by the NPM proponents as a substitute for the traditional cash accounting system of public administration ${ }^{16}$. This enthusiastic endorsement is based on the prospect of enhanced information: valuation of assets; pictures of claims on these resources, explicitly showing debt exposure; an evaluation of the revenues and costs incurred in a specific period, including the use of assets (depreciation and amortisation) (Arnaboldi \& Lapsley, 2009: 813). 
However, there is also a substantial number of senior academic specialists on public sector accounting systems who have expressed major concerns over the value and efficiency of accrual accounting in the public sector. For example, Humprey (2006: 483) ${ }^{17}$ believes that it is something that few seem to understand, and that even fewer seem to be worried about the commitment of relatively scarce public funds to a relatively mysterious project that has a questionable direct capacity to deliver better public services, more meaningful and reliable assessments of the general health, the standing of such services, and the valuation of the related public sector assets.

Since the 1990s, increasing numbers of governments have been adopting accrualbased accounting for all the parts of their public sector, including the general government sector. This change has been no less pervasive in Europe (Lüder and Jones, 2003; in Christensen, 2005: 447) because many European countries have now adopted or are committed to adopt some variant of public sector accrual accounting. (This topic is discussed in more detail in Section 5.)

\subsection{Accounting Regulation of Business Relationships between Public Enterprises and Municipalities in Slovenia}

It has been previously indicated that in Slovenia, a public enterprise is defined in the Public Utilities Act as one of the forms of rendering public services. The issue of facing difficulty in defining public enterprises has also been raised.

The Slovene Accounting Standard 35 (SAS 35) Accounting Monitoring of Public Utility Services $^{18}$ regulates public enterprise accounting in Slovenia. This standard stipulates that the standard provisions are compulsory for the enterprises pursuant to the criteria in the Companies Act ${ }^{19}$. In addition, they are also recommended for all the enterprises engaged in providing public utility services. However, as of 31 December 2009, the provisions of SAS 35 related to 'assets under management' are abandoned. In compliance with these provisions, public enterprises have to report the 'assets under management' for infrastructure owned by the municipality on the one hand, and the liability towards the municipality on the other. The infrastructure (i.e., buildings, machinery, networks) owned by the municipality is entrusted for management to public enterprises on the basis of a management contract.

There are many reasons why this particular segment of SAS 35 was abandoned. SAS 35 is a specific Slovene accounting standard that deals with the accounting particularities in public enterprises. The $\mathrm{SASs}^{20}$ that define the accounting of companies or corporate entities must not be in conflict with the Companies Act and any other acts regulating the accounting of individual legal entities, and they 
must not be in conflict with the regulations based on these acts either. In addition, according to the Companies Act (Article 53), the SASs must not be in conflict with the International Financial Reporting Standards (hereinafter referred to as IFRSs ${ }^{21}$. Since the IFRSs do not define the 'assets under management' category for public enterprises, there is no legal basis for such a provision in the SASs. In addition, the Companies Act does not define 'assets under management' as such. Therefore, a new system had to be set up in Slovenia as of 1 January 2010 for reporting of relationships between public enterprises and budget organisations or local communities, i.e., municipalities.

A public enterprise has to depreciate all the depreciable assets in compliance with the Slovene Accounting Standard 13 (SAS 13) Depreciation. Depreciation has to be reported separately for the performance of public utilities and for the performance of other activities.

On the other hand, municipal accounting in Slovenia must mainly comply with the provisions of the following acts: the Public Finance $\mathrm{Act}^{22}$, the Accounting $\mathrm{Act}^{23}$, the Rules on Drawing up Annual Reports for the Budget, Budget Spending Units and other Entities of Public $\mathrm{Law}^{24}$, and with other rules that define the preparation of annual reports pursuant to the Accounting Act.

The SAS provisions are also applied in the treatment of individual accounting items should their treatment not be regulated under the Accounting Act and by implementing regulations (Čižman, 2009: 7-10). The Accounting Act defines the accounting aspect of the entire non-profit sphere in Slovenia (Kokotec-Novak, 2001: 245).

In accordance with the Accounting Act and other rules mentioned above, the annual report must comprise the following financial statements: balance sheet, statement of revenues and expenses, and business report. The compulsory annexes to the balance sheet are presentation of balances, changes in intangible fixed assets and tangible fixed assets, and the balances and changes in long-term investments and loans. The compulsory annex to the statement of revenues and expenses is the statement of revenues and expenses of individual users per type of service. In addition, it is necessary to enclose the cash basis statement of revenues and expenses of individual users, the list of financial receivables and investments as well as the statement of financing.

The discussion so far clearly points out that accounting for budget users, i.e., municipalities, is a cash basis accounting system, which is also emphasised in the Accounting Act. However, according to the Rules on Drawing up Annual Reports for the Budget, Budget Spending Units and other Entities of Public Law, external financial reporting also includes the elements of the accrual basis of accounting. 
We can thus conclude that the system under discussion is actually a modified cash-basis system of accounting ${ }^{25}$.

The changes in the regulation of the relationships between public enterprises and municipalities in Slovenia were required as can be seen from the discussion so far.

On 1 July 2009, the Ministry of Finance of the Republic of Slovenia adopted the 'Recommendation for the regulation of relationships between the public infrastructure owner, i.e., municipality, and the public utility provider ${ }^{26}$.

This Recommendation applies only to the regulation of relationships between the public infrastructure owner, i.e., municipality, and the public enterprises that are 100 percent owned by the municipality.

The Ministry of Finance has established that the legal bases for the new regulation of the relationships between public enterprises and municipalities are as follows: the Companies Act, the Public Utilities Act, the Spatial Planning Act ${ }^{27}$, and the Transparency of Financial Relations and Maintenance of Separate Accounts for Different Activities Act. In the Recommendation mentioned above, the Ministry of Finance points to a mismatch in certain regulations with regard to the governing of relationships after the transfer of public utility infrastructure into municipal ownership, or upon the termination of reporting of 'assets under management'. According to the Ministry, there is a mismatch between the Physical Assets of the State, Regions and Municipalities $\mathrm{Act}^{28}$, the Public Finance Act, and the Environment Protection $\mathrm{Act}^{29}$.

After adopting the Physical Assets of the State, Regions and Municipalities Act, all the provisions stipulating the management of physical assets of the state and municipalities were deleted from the Public Finance Act.

In this Recommendation, the Ministry of Finance of the Republic of Slovenia proposes the following possible ways of governing the relationships: a transfer of ownership of public infrastructure to a public enterprise, a financial lease, and an operating lease.

The Ministry of Finance believes that the transfer of public infrastructure ownership to a public enterprise is problematic because the legislation in force does not provide adequate solutions. Namely, in the case of transferring public infrastructure into the ownership of the public enterprise, the legislation should change the definition of sources of finance. The public utility charges should be replaced by other sources of public utility financing and not by municipal resources. In this case, the resources for financing new investments should be accumulated in the public enterprise. However, the current legislation, particularly 
the Public Finance Act, does not allow that. In addition, the problems that might arise in the future considering the agreements on financing the public infrastructure renewal should be foreseen.

The transfer of ownership to public enterprises could also mean the transfer of a public monopoly to a private monopoly. In current circumstances, the transfer of public infrastructure into the public service operator ownership thus presents a huge risk to the state or municipality in terms of ensuring the public services. As a result, it is not recommended.

According to the Ministry of Finance, the finance lease is not an option because the SASs and the IFRSs define a finance lease as a lease in which all the risks and rewards incident to the ownership of an asset are transferred to the lessee, while the ownership of a leased asset may be transferred or not (Duhovnik, 2006: 77). In the case of a finance lease, municipalities (as lessors) have to comply with the provisions of the Public Finance Act (Lozej, 2006: 53).

The Ministry of Finance recommends an operating lease. It should be acknowledged that pursuant to Article 80 of the Public Finance Act, the lease income from leasing the physical assets is defined as dedicated revenue ${ }^{30}$ and thus may be used only for the construction, purchase, and maintenance of physical assets.

In view of budget preparation and implementation, the dedicated sources of financing public infrastructure renewal investments are thus guaranteed. The above-mentioned Transparency of Financial Relations and Maintenance of Separate Accounts for Different Activities Act regulates the relationship between the public infrastructure owner and the public service operator. Pursuant to this Act, transparency will be exhibited if all the public service implementation costs are stated in the full amount with budget subsidies covering potential losses.

Here, the stipulations from the contract on public infrastructure lease and public service implementation will be of key importance. Apart from public infrastructure lease, all other elements related to public service implementation will have to be defined (service prices, allocation of overheads).

Within this context, the following problems might arise: public infrastructure investment management, setting the lease payments for public infrastructure and the subsidies for public service implementation, the increased obligations of municipalities, and ensuring the liquidity of public enterprises.

On 31 December 2009, all the 'assets under management' recorded in books of account of public enterprises had to be transferred to the owner's books of account 
(i.e., the state or municipality). Therefore, the state or municipality must record the tangible fixed assets ${ }^{31}$ and the general fund for tangible fixed assets. Here, the problem of valuating these assets arises - should they be reported at their book value according to the public enterprise records, or should a preliminary valuation of these assets be made (this is up to the municipalities to decide).

Public infrastructure assets shall be depreciated in the state or municipal books of account, pursuant to the Rules of Tariff System for Public Service in the Environmental Field ${ }^{32}$, while until 31 December 2009 in public enterprise books of account the 'assets under management' were depreciated in compliance with the SASs.

Characteristics of Reporting Business Relationships between Public Enterprises and Municipalities - the Case of the Water Sector in Slovenia, Austria, and Italy

In the mid-1980s, Europe saw the liberalisation of 'infrastructure sectors', especially the electricity market, natural gas, transport, telecommunications, and postal services (Obermann and Soukup, 1992: 315-334).

The water sector liberalisation, which includes drinking water supply as well as wastewater treatment and discharge, was less frequent. This is mainly due to the specific form of local natural monopolies and strong impacts on the health of inhabitants and on natural environment (Hansen, 2004: 105-121). Consequently, local level management is typical of the water sector.

The water sector management in the European Union may be defined as either direct or indirect public management by transfer of powers, indirect private management or direct private management. Direct public management prevails in Denmark, Luxembourg, Switzerland, Sweden, Austria, Finland, Ireland, Germany, the Netherlands, and Belgium. However, this traditional model is being transformed into indirect management that can especially be noticed in Germany, Belgium, Switzerland, the Netherlands, Italy, and Greece. The inclusion of private companies in water supply based on concession arrangements has been gaining importance in France and Spain. Within the framework of direct private management, both activity implementation and infrastructure ownership are transferred to a private company. This approach is used in the United Kingdom (Cerkvenik, 2008: 15-17).

When analysing provisions for water sector operations in Slovenia, Austria and Italy, we have found out that the core legislation is in compliance with the EU regulations and guidelines. Here, Directive $2000 / 60 / \mathrm{EC}^{33}$ in the field of water policy is of primary importance because it sets the legal framework for providing 
sufficient quantities of good quality water in Europe by taking into account environmental costs and benefits. It also includes the principle of full cost recovery and efficient use of water resources.

\subsection{Accounting Aspects of Reporting Business Relationships between Public Enterprises and Municipalities in the Water Sector in Slovenia}

The Slovene legislation regulates water sector operations in the Water $\mathrm{Act}^{34}$, the Environment Protection Act, and in the Rules of Tariff System for Public Service in the Environmental Field. Slovenia exhibits a high level of dispersion of water supply system operators among which public enterprises prevail. The analysis in the 2008 research showed the following structure of drinking water suppliers: $70 \%$ of them were public enterprises, $25 \%$ of them were public utility units, and $5 \%$ of them were concessionaires (Energy, Ecology and Technology Research Institute, 2008: 34-36).

Although Slovenia adopted the Public-Private Partnership Act in 2006, the above mentioned study clearly showed the prevalence of the public enterprises in Slovenia's water sector, which was later confirmed by Grafenauer (2009: 215216).

According to the 2008 study, the water price charged to Slovene customers covered only $78.6 \%$ of the (full) cost per unit. The key factor for that was the public enterprises' inability to cover the entire depreciation needed to provide internal financing for normal infrastructure renewal. Normally, in that case, public enterprises would report operating losses. However, the public enterprises generated additional revenues by debiting their liabilities to municipalities whose infrastructure they had 'under management'. ${ }^{35}$ Thus, these bookkeeping entries prevented losses, but had no effect on cash flows. Consequently, public enterprises did not generate enough operating cash flows to provide for infrastructure renewal (Halužan, 2009b: 11-13).

In compliance with the above-mentioned Recommendation by the Slovene Ministry of Finance, public enterprises shall make lease payments for infrastructure use. The lease payments shall be charged according to the Transparency of Financial Relations and Maintenance of Separate Accounts for Different Activities Act and the Rules of Tariff System for Public Service in the Environmental Field in the amount of depreciation and interest (if the infrastructure is financed by loans). The legislation also defines that the lease payments for the public utility infrastructure use are dedicated revenues of municipalities. They can only be used for new investments and investment maintenance work on the infrastructure. These stipulations put the municipalities 
into the role of an appropriate manager of public infrastructure. From an accounting perspective, this requires cost management and adequate calculation of lease payments. Otherwise, the management of the sector under discussion would not be possible from the economic aspect. These facts will thus require pertinent changes in the municipal accounting system because the current modified cashbasis accounting system does not provide such information. Public enterprises will have to recognise these lease payments under operating leases as expenses, which will consequently have a significant impact on their liquidity and performance.

\subsection{Accounting Aspects of Reporting Business Relationships between Public Enterprises and Municipalities in the Water Sector in Austria}

The most important act regulating the water supply in Austria is the Water Rights Act (Wasserrechtgesetz - BGBl 87/2005) upon which the environment protection legislation of individual federal states is based. The water sector operations are also regulated by the Public Finance Act (Finanz-Verfassungsgesetz - BGB1 45/1948) and by the Financial Equalisation Act (Finanzausgleichgesetz - BGB1 103/2007).

In Austria, municipalities provide water supply predominantly via municipal utility companies $(90 \%)$, whereas private companies perform the remaining part. Despite the fact that the water price charged to customers should cover the (full) cost per unit of water, the water supply is still partly subsidised by the government and the federal states due to the compliance with the Financial Equalisation Act. Nevertheless, there is a trend of reducing subsidies (Energy, Ecology and Technology Research Institute, 2008: 57-59).

The operations of municipalities are governed by federal state (Länder) legislation. In Carinthia, the 'General Decree for Municipalities' (Sturm, 2009) regulates the municipal activities. Apart from the general provisions for municipal activities, the budget-related provisions also define the relationships between a municipality and enterprises that perform public services. Public services within the public sector are mainly carried out by public enterprises whose legal form is either a corporate entity or a public utility unit. If public services are rendered by public enterprises, the municipal ownership is clearly stated in them. The relationship regarding the public service implementation is stated in the contract between the municipality and the public enterprise. The municipal council has an insight into the public enterprise operations.

Public enterprise accounting is governed by the legislation that regulates accounting for corporate entities. Municipal accounting is mainly cash-based and is in accordance with the legal acts regulating municipal activities. Therefore, the 'Municipal Budget Regulation for Carinthia' is in force for municipal accounting 
in Carinthia (Sturm, 2003). This regulation stipulates that the annual accounting report of a municipality must include the cash flow statement of the municipality as well as the statement of municipal assets, which must include not only the statement of tangible and financial assets, but also the stakes in individual enterprises. Financial reporting by municipalities in Austria was examined within the 'Municipal Financial Report of the Alliance of Municipalities in Carinthia 2009' (i.e., Kärntner Gemeindebund, 2009). According to the opinion of the municipal management, more accounting information would be needed about the business relationships between municipalities and public enterprises.

It may therefore be ascertained that municipal accounting in Austria has features of modified cash-basis of accounting, while public enterprises prepare their financial statements in compliance with the legislation that regulates corporate entities, i.e., under the full accrual basis of accounting.

\subsection{Accounting Aspects of Reporting Business Relationships between Public Enterprises and Municipalities in the Water Sector in Italy}

The fundamental legal basis for the water sector operations in Italy is Act No. 36 that includes provisions on waters36. This Act aims to encourage water sector cost efficiency by price regulation. In addition, Act No. 135/2009, which was coordinated with Act No. 166/2009 (i.e., 'Urgent provisions for the performance of the obligations within the European Union and implementing judgments of the Court of Justice of the European Communities ${ }^{37}$ ), must also be taken into account.

In Italy, the infrastructure, particularly the water supply and sewage network, remains publicly owned, but its management is handed over to operators and service providers via concession arrangements. In small municipalities with a few thousand inhabitants, however, the municipalities themselves through their own municipal services still directly manage the water service and water supply. Namely, the municipalities assign the management of the implementation of local water management services, while the regions supervise the compliance with environmental provisions on waste management and wastewater management. Either one or more operators implement the services. They may be either public or private entities.

The relationships between local government and the operators are regulated by the service implementation contract. Although water prices are relatively high compared to the rest of Europe, the prices generally cover only the current operating costs without depreciation, and thus do not provide funds necessary for new investments. That is why budgetary co-financing is required (Energy, Ecology and Technology Research Institute, 2008: 50-53). 
Act No. $267^{38}$ regulates the operations of municipalities, i.e., local communities. Article 113 of this Act is of particular importance because it stipulates the conferment of public utilities (private entities, joint ventures, and other companies). The system of conferment is constantly changing either by the annual financial act (approved by Parliament alongside the budget) or by ad hoc interventions that have been attempting to completely privatise public utilities ever since 2001. However, these attempts have met with a strong opposition by the municipalities, especially as regards water resources. The Act No. 267 also stipulates the method of municipal accounting, i.e., it requires the cash-basis accounting system.

Based on the analysis of the annual report given by the public enterprise Kraški vodovod d.d. / Acquedotto del Carso S.p.A. that manages the water supply network of the three Karst municipalities in Italy (Repentabor, Zgonik and DevinNabrežina), it can be ascertained that this company (with its seat at Nabrežina) carries out its operations with the municipal assets and thus reports on municipal ownership in its financial statements. The annual report is created in compliance with the legislation regulating corporate entities. We also analysed the annual report of the Municipality of Zgonik in Trieste Province - Comune di Sgonico Provincia di Trieste. The Municipality of Zgonik prepares its annual report mainly on the cash basis. It also prepares the List of assets (Consistenza del patrimonio) that includes a separate heading - participation in controlled enterprises, i.e., participation in a public enterprise (e.g., Kraški vodovod). Business relationships between the public enterprise Kraški vodovod and the Municipality of Zgonik are regulated by a contract.

By analysing the accounting aspect of reporting of public enterprises and municipalities in Italy, we can conclude that public enterprises prepare their financial statements in compliance with the legislation regulating corporate entities. On the other hand, the municipalities are obliged to apply the modified cash basis of accounting where they have to report not only on their cash flows, but also on municipal assets, including the stakes in public enterprises. However, there is a clear need in municipalities for more comprehensive accounting information because the mentioned basis of accounting does not provide enough information about the realistic value of the municipal stake in public enterprises. 


\section{The Influence of EU Regulations and IFRS on Accounting Aspects of Business Relationships between Public Enterprises and Municipalities}

After analysing the accounting aspects of the relationships between public enterprises and municipalities within the EU, it has been found out that the European legislation mainly emphasises transparent financial reporting of relations in private-public partnerships.

To this end, the Commission Regulation (EC) No. 254/2009 ${ }^{39}$ was adopted in March 2009. The Regulation incorporates the Financial Reporting Standard Interpretations Committee ${ }^{40}$ (IFRIC) Interpretation 12 Service Concession Arrangements regarding the recording of infrastructure subject to the service concession arrangements into the acquis communautaire. The above Regulation stems from Regulation (EC) No. 1606/2002 which states that for each financial year starting on or after 1 January 2005, the publicly-traded companies (companies whose securities are admitted to trading on a regulated market; listed companies) governed by the law of a Member State shall prepare their consolidated accounts (financial statements) in accordance with the IFRSs endorsed by the European Union ${ }^{41}$.

IFRIC 12 (i.e., Commission Regulation (EC) No. 254/2009) does not specify the accounting by grantors (public partners) mainly because of IFRIC's view that in many cases, the grantor is a government body and that IFRSs are not designed to apply for not-for-profit activities in the private sector, the public sector or government, though entities with such activities may find them appropriate (IFRIC 12.BC15). However, Jereb and Petrovič (2008: 26) write that the Regulation in fact indirectly stipulates that the infrastructure shall always be reported as a tangible fixed asset of the public partner (i.e., municipality, state) provided that the following two conditions are met: the public partner (grantor) should control or regulate the services the operator must provide with the infrastructure, to whom it must provide them, and at what price; and the public partner should control (through ownership, beneficial entitlement or otherwise) any significant residual interest in the infrastructure at the end of the term of the arrangement. ${ }^{42}$

On the other hand, the International Public Sector Accounting Standards Board (IPSASB), an independent standard-setting body within the International Federation of Accountants (IFAC) ${ }^{43}$, approved the Exposure Draft, ED 43, Service Concession Arrangements: Grantor ${ }^{44}$ in February 2010. The proposals in the ED 43 may be modified in light of the comments received by June 30, 2010 before being issued in its final form. The future Standard that will be developed from the ED 43 is intended to mirror the IFRIC 12 (i.e., Commission Regulation 254/2009) 
that gives guidance on the accounting by operators in service concession arrangements. Accordingly, the scope, the principle for recognition of an asset and terminology are derived from IFRIC 12. ED 43 also includes disclosure requirements adapted from those set out in Interpretation 29 of the IASB's former Standing Interpretations Committee (SIC 29), Service Concession Arrangements: Disclosures. However, the IPSASs apply to all public sector entities other than Government Business Enterprises (GBEs) ${ }^{45}$. The 'Preface to International Public Sector Accounting Standards' issued by the IPSASB explains that GBEs apply International Financial Reporting Standards (IFRSs), thus also IFRIC 12, issued by the London-based IASB. The link between the International Public Sector Accounting Standards (the IPSASs) ${ }^{46}$ and the IFRSs is hence quite apparent. But the application of IFRSs by GBEs is sometimes impeded, especially if the local legislation does not allow the application of the IFRSs for the GBEs. For example, in Slovenia where public enterprises are arguably a form of GBEs, the Slovene Accounting Standard 35 (SAS 35) must be applied, i.e., the 'Accounting Monitoring of Public Utility Services' standard with no option for direct application of IFRS. However, as already mentioned, the SASs must not be in conflict with the IFRS, so IFRSs have a big influence on Slovene accounting ${ }^{47}$.

As already mentioned, the IPSASs are developed and issued by the Public Sector Accounting Standards Board (IPSASB) ${ }^{48}$ within IFAC. IFAC is a professional organisation. Therefore, the IPSASs only act as recommendations and not as legislation. They acquire legislative power if they are implemented into the legislation of individual countries.

The IPSASB's goal is to serve the public interest by developing high quality accounting standards for use by public sector entities (national, regional and local governments, related governmental agencies, but not GBEs) around the world in the preparation of general-purpose financial statements. This will enhance the quality and transparency of public sector financial reporting and strengthen public confidence in public sector financial management. In pursuit of this objective, the IPSASB supports the convergence of international and national public sector accounting standards and the convergence of accounting and statistical bases of financial reporting where appropriate. A key part of the IPSASB's strategy is to converge the IPSASs with the IFRSs issued by the IASB. To facilitate this strategy, the IPSASB has developed guidelines or 'rules of the road' for modifying IFRSs for application by public sector entities. The IPSASs comprise 31 accounting standards for financial reporting under the accrual basis of accounting (i.e., accounting that is typical of double-entry bookkeeping and of the private sector), which basically cover the same topics of accounting and financial reporting as the IFRSs while taking into consideration public sector specifics. In addition, there is a separate standard for financial reporting under the cash basis of accounting. 
The need for the IPSASs has arisen because public sector financial reporting is still quite non-transparent, and provides no insight into the actual situation of the assets, financing and performance (true and fair view ${ }^{49}$ ) of the public sector because the financial statements in the public sector of most countries are based on cameralistic accounting, i.e., on cash basis accounting or its modified forms. For that reason, the politicians and citizens have insufficient insight into the public sector's economic situation. In addition, this type of information is not an adequate basis for management and supervision processes in the public sector ${ }^{50}$.

Financial reporting according to the IPSASs is important also from the international aspect of public sector comparability. There is a plethora of different accounting regulations for the public sector. That is why, for example, the annual accounts of a local authority in one country are not comparable with the annual accounts of local authorities in other countries. This issue may prove problematic, especially when comparable information is needed in order to obtain funds either as subsidies or as grants from international institutions (the UN, the World Bank, the EU, etc.). In this respect, the application of the IPSASs would largely simplify the procedures. At the same time, since the public sector is usually also reliant on financing through credit and borrowing, a standardised system of accounting would considerably simplify the valid assessment of the efficiency of public institutions and their rating, which would hence reduce the public sector creditors' risk exposure.

A complete set of financial statements under IPSAS comprises (IPSAS 1.21):

(a) A statement of financial position;

(b) A statement of financial performance;

(c) A statement of changes in net assets/equity;

(d) A cash flow statement;

(e) When the entity makes publicly available its approved budget, a comparison of budget and actual amounts either as a separate additional financial statement or as a budget column in the financial statements; and

(f) Notes, comprising a summary of significant accounting policies and other explanatory notes.

By gradual implementation of double-entry bookkeeping based on accrual basis of accounting, individual European countries try to integrate certain elements of the IPSASs. The United Kingdom took this approach in the 1990s, France followed in 2006, and Switzerland in 2007. In Germany, there are differences between individual federal states. Namely, the federal states (Länder) Hamburg, Hessen, and Nordrhein-Westfalen have adopted the principles of accrual basis of accounting, while 'extended' cameralistic accounting is prevalent at the federal government level in Germany. Austria also shows attempts to modernise public sector accounting. The foundations for the reform, which is to be effected by 
2013, were thus established and published in BGB1I 1/2008. The adoption of the accrual basis of accounting would contribute to the measurement of costs and effects, the flexibility of management, and also to a better transparency and understanding of the budgets (Hauth, 2009: 4-7). Pina et al. (2009) discuss the implementation of accrual accounting in local governments at the European Union level in more detail. However, it can be determined that the approaches taken by individual countries to adopt double-entry bookkeeping based on accrual basis of accounting are not fully harmonised with the IPSASs. ${ }^{51}$

Slovenia is currently not among the countries adopting the IPSASs despite the fact that a study group at the Centre of Excellence in Finance within the Ministry of Finance is involved in the IPSASs research (http://www.crf.si/). Thus, we believe that eventually the public sector accounting reform in the direction of the IPSASs can also be expected in Slovenia. Consequently, this would contribute to a greater transparency of the public sector and to the introduction of the NPM principles as a modern system of public sector management.

\section{Conclusion}

In Slovenia, a number of problems related to the reporting of business relationships between public enterprises and municipalities have arisen from the accounting aspect due to the changes that came into force on 1 January 2010.

In this paper, we presented the solutions proposed by the Ministry of Finance of the Republic of Slovenia to lay down ground rules for the arrangement of relationships between municipalities and public enterprises under 100 percent municipal ownership. We have also pointed out the problems that will arise due to a mismatch in the legislation and the new role of municipalities regarding infrastructure management. This will require enforcing the new mode of municipal management, particularly regarding cost management and the respective accounting solutions.

In the water sector, the Slovene municipalities must apply the modified cash basis accounting principles. However, the new mode of reporting relationships between public enterprises and municipalities raises the issue of the amount of the operating lease payments that the municipalities need to charge public enterprises. The lease payments ought to cover the infrastructure depreciation and eventual interest. Public enterprises must recognise these lease payments under operating leases as expenses, which will consequently have a significant impact on their liquidity and performance.

From the accounting point of view, reporting business relationships between public enterprises and municipalities in Italy and Austria in the water sector is 
more clearly defined and included in the regulations defining municipal operations. We have found out that public enterprises prepare financial statements in compliance with the legislation regulating corporate entity accounting, while the municipalities prepare their financial statements based on the legislation regulating municipalities. In the latter case, the modified cash-basis accounting principles apply. During the interviews with the heads of municipalities, the need for a more comprehensive approach to accounting was pointed out. Namely, despite clearly defined regulations, the transparency of information provided by the current accounting system is rather low.

The concept of New Public Management (NPM), a model of the public sector reform that privileges quantification and results, and where accounting has a central role, is gaining in importance. Therefore, many European countries have now adopted or committed to adopt some variant of accrual accounting also for the public sector. However, the accrual accounting is usually first adopted in those areas in which it can be adopted more easily without incurring additional data collecting costs.

Therefore, eventually some kind of accrual based accounting reform can be expected in the public sector in Slovenia, Austria, and Italy. This would contribute to a greater transparency of public sector and to its increased comparability with the private sector. Since there is a plethora of different accounting regulations for the public sector, large-scale adoption of the International Public Sector Accounting Standards (the IPSASs) issued by IFAC's International Public Sector Accounting Standards Board (IPSASB), or the accounting standards that are broadly consistent with IPSAS would significantly increase the international public sector comparability. It is worth noting that for studying IPSASs, there is a special group within the Ministry of Finance of the Republic of Slovenia.

\footnotetext{
Notes

${ }^{1}$ The public sector comprises the following elements: state administration (government offices, ministries with their affiliated bodies and branch offices, administrative units), local selfgovernment, public (for profit) utilities, political system, education and research domain, health and social security sector, and culture (Setnikar-Cankar et al., 2008: 41).

2 Public Utilities Act (OJ RS, No. 32/1993, 30/1998, 127/2006).

3 Transparency of Financial Relations and Maintenance of Separate Accounts for Different Activities Act (OJ RS, No. 53/2007, 65/2008).

${ }_{4}^{4}$ Brezovnik and Oplotnik (2003: 143) have ascertained that concessions and public-private partnerships are not frequently applied, and that the public-private partnerships could contribute to the increased public sector efficiency.

${ }_{5}^{5}$ Public-Private Partnership Act (OJ RS, No. 127/2006)

${ }^{6}$ Local Self-Government Act (OJ RS, No. 100/2005).

${ }^{7}$ See Oplotnik and Brezovnik (2004) for a short history of local self-government in Slovenia.
} 
8 While the use of information can be different across strategic and nonstrategic settings, demand for information can also arise for different reasons. In general, economic agents may demand information for production purposes (e.g., choosing which project to pursue), for consumption/investment purposes (e.g., choosing how much to save) and for contracting purposes (e.g., choosing the best sharing rules) (Liang, 2001: 233).

${ }^{9}$ For more information, please refer to Novak (2008b: 531-535).

10 Actually, financial reporting has both an internal and external aspect. However, the term 'financial reporting' is usually used in place of the term 'general-purpose external financial reporting'.

11 However, these recipes for public sector reform, with their origin in Anglo-American countries, have been adapted, rather than adopted, in other counties with different public administration styles. The implementation process has undergone multiple variations and variations across counties (Pina et al., 2009: 766).

${ }^{12}$ The focus of cameralistic accounting is mainly on the measurement and control of budgetary means spending. In order to stress the importance of the budget, the term 'budgetary accounting' is often used to refer to cameralistic accounting (Christiaens, 2004: 744).

13 The modified cash basis of accounting is the pure cash basis of accounting with modifications that have substantial support, such as capitalising and depreciating plant assets or recording inventory (Kieso et al., 2005: 95).

$14 »$ Value-for-money« is about achieving the right local balance between economy, efficiency and effectiveness - spending less, spending well, and spending wisely. For more information, please refer to Setnikar-Cankar et al. (2008), Seidel and Temmen (2007), and Wilson and Kattelus (2004).

15 Some authors, e.g., Zimmermann (1999: 293), emphasise the introduction of 'public controllership' as s special brand of controllership (i.e., managerial accounting) for public sector.

16 The initial pressure to shift from cash accounting to accrual accounting was proposed in Australia and New Zealand during the 1980s (Arnaboldi and Lapsley, 2009: 813). In Australia, the set of professional accounting standards and concepts (GAAP) developed for the business sector has been applied to the public sector as part of the process of adopting accrual accounting. Barton (2005) claims that this sector-neutral approach ignores the differences in the roles and operating environments, and labels the above application as not a particularly successful one. Carnegie and West (2005) have also emphasised that there remain many important questions of public sector accounting developments that have not been satisfactorily answered by those promoting reform. In their view, there is a continuing need to make accounting more accountable in the public sector.

${ }^{17}$ Humprey (2006: 478) also provides quite exhaustive list of papers expressing concerns about accrual accounting in the public sector and NPM in general.

18 Slovene Institute of Auditors (2005) Slovene Accounting Standards (OJ RS, No. 118/2005, $7 / 2010)$.

${ }^{19}$ Companies Act (OJ RS, No. 42/2006, 10/2008, 68/2008, 23/2009).

20 The Slovene Accounting Standards (SASs) include a fundamental accounting assumption of the occurrence of a business event (Novak, 2007: 118). We can thus talk about full accrual basis of accounting.

${ }^{21}$ International Financial Reporting Standards (IFRSs) are Standards and Interpretations adopted by London-based International Accounting Standards Board (IASB). They comprise (IAS 1.7):

a) International Financial Reporting Standards;

b) International Accounting Standards (IAS), and 
c) Interpretations developed by the International Financial Reporting Standard Interpretations Committee (IFRIC) or the former Standing Interpretations Committee (SIC).

22 Public Finance Act (OJ RS, No. 79/1999, 124/2000, 79/2001, 30/2002, 50/2002, 11/2002, 127/2006, 14/2007, 109/2008).

${ }^{23}$ Accounting Act (OJ RS, No. 23/1999, 30/2002).

${ }^{24}$ Pravilnik o sestavljanju letnih poročil za proračun, proračunske uporabnike in druge osebe javnega prava - Rules on Drawing up Annual Reports for the Budget, Budget Spending Units and other Entities of Public Law (2002) (OJ RS; No. 115/2002, 21/2003, 134/2003, $126 / 2004,120 / 2007,124 / 2008$ ).

25 The accounting practices actually applied by some EU local governments transform the legally required full accrual basis into some kind of modified accrual basis, especially in some Southern European cities such as French and Italian (Pina et al., 2009: 795). Thus a distinction should be made between accounting regulations, or de iure issues, and actual practices, or de facto issues (Roberts et al, 2002: 61).

26 Priporočilo za ureditev razmerij med lastnikom gospodarske javne infrastrukture - občino in izvajalcem gospodarske javne službe - Recommendation for the regulation of relationships between the public infrastructure owner, i.e., municipality, and the public utility provider (2009) (Ljubljana: Ministrstvo za finance Republike Slovenije - dopis z dne 1. 7. 2009).

${ }^{27}$ Spatial Planning Act (OJ RS, No. 33/2007, 70/2008-ZVO-1B).

${ }^{28}$ Physical Assets of the State, Regions and Municipalities Act (OJ RS, No. 14/2007).

${ }^{29}$ Environment Protection Act (OJ RS, No. 39/2006, 49/2006, 66/2006, 51/2006, 112/2006, 33/2007, 57/2008, 70/2008).

${ }^{30}$ Budget revenue could be either dedicated or non-dedicated revenue. A dedicated revenue is the one where the revenue is used for a specific service associated with the revenue. For example, a transit fare is a dedicated revenue for transit operations; an overdue book fine is dedicated to the library; a water utility payment is dedicated to the operations of the water utility. A non-dedicated revenue is the one where the the revenue can be used for any purpose it is deemed appropriate.

${ }^{31}$ It is worth noting that in IFRSs the term property, plant and equipment (PPE) is used for tangible fixed assets.

32 Pravilnik o metodologiji za oblikovanje cen storitev obveznih občinskih gospodarskih javnih služb varstva okolja - Rules of Tariff System for Public Service on the Environmental Field (2009) (OJ RS, No. 63/2009).

33 Directive 2000/60/EC of the European Parliament and of the Council of 23 October 2000 establishing a framework for Community action in the field of water policy, OJ L 327, 22.12.2000, pp.1-73 (ES, DA, DE, EL, EN, FR, IT, NL, PT, FI, SV).

${ }^{34}$ Water Act (OJ RS, No. 67/2002, 110/2002, 2/2004, 41/2004, 57/2008).

35 In her master's thesis, Halužan (2009a: 22-71) analyses in great detail the business and taxation aspect of depreciation in public utilities operations in Slovenia.

36 Disposizioni in materia di risorse idriche $-14 / 1994$. This Act has been amended many times. Finally, its provisions were included in the 'Environment Act' - Act No. 152 Codice dell'ambiente $-88 / 2006$.

37 Disposizioni urgenti per 1 attuazione di obblighi comunitari e per l'esecuzione di sentenze della Corte di giustizia delle Comunita europee - 223/2009, 274/2009. Article 15 of this Act is of particular importance because it stipulates the adjustment to the European provisions on public utility services.

${ }^{38}$ Testo unico degli Enti locali - 267/2000. 
${ }^{39}$ Commission Regulation (EC) No 254/2009 of 25 March 2009 amending Regulation (EC) No 1126/2008 adopting certain international accounting standards in accordance with Regulation (EC) No 1606/2002 of the European Parliament and of the Council as regards International Financial Reporting Interpretations Committee's (IFRIC) Interpretation 12, OJ L 80, 26.3.2009, pp. 5-13.

${ }^{40}$ The IFRIC is the interpretative body of the IASB. The IFRIC comprises 14 voting members appointed by the Trustees and drawn from a variety of countries and professional backgrounds. The mandate of the IFRIC is to review on a timely basis widespread accounting issues that have arisen within the context of current IFRSs and to provide authoritative guidance (IFRICs) on those issues. IFRIC meetings are open to the public and webcast. In developing interpretations, the IFRIC works closely with similar national committees and follows a transparent, thorough and open due process. Source: IASB - International Accounting Standards Board (2010) The IFRIC (International Financial Reporting Interpretations Committee). http://www.iasb.org/The+organisation/IASCF+and+IASB.htm [Accessed 7 February 2010].

${ }^{41}$ See Van Hulle (2004) for more information on the endorsement process of IFRSs in the European Union. On 3 November 2008, the European Commission issued Comission Regulation (EC) No 1126/2008 in order to include all the standards [presented by the International Accounting Standards Board (IASB)] and all the interpretations (presented by IFRIC and which were adopted within the European Union by 15 October 2008) into a single official document within acquis communautaire. Technically speaking, the Commission Regulation (EC) No 254/2009 of 25 March 2009 thus inserts the IFRIC 12 as an Annex to Regulation (EC) No 1126/2008.

42 Jereb and Petrovic (2008: 26-27) also state that one of the aims of the Commission Regulation (EC) No. 254/2009 is to ensure the comparability of the EU Member States in terms of reporting the scope of public partners' (i.e., the municipalities, the state) borrowing. Namely, the Regulation is based on the assumption that the public partner has the obligation to provide the infrastructure for the implementation of this activity. That is why any infrastructure financing arrangement other than from the budget is de facto public partners' borrowing. The reporting on the scope of public partners' borrowing at the EU Member State level is highly significant for the Maastricht criteria compliance. Pursuant to Article 104 of the Treaty of European Union, the Member States should avoid excessive government deficits (Protocol on the Excessive Deficit Procedure; EDP). The Annex to the Treaty stipulates that the data for its implementation are to be prepared by the Commission supported by individual Member States. Detailed provisions for the implementation of the protocol are set out in the Council Regulation (EC) No 3605/93.

43 The International Federation of Accountants (IFAC) was founded in Munich, Germany, at the 11th World Congress of Accountants on 7 October 1977. The organisation headquarters have been based in New York City since its founding. IFAC is the global organisation for the accountancy profession. It works with its 159 members and associates in 124 countries and jurisdictions to protect the public interest by encouraging high quality practices by the world's accountants. IFAC members and associates, which are primarily national professional accountancy bodies, represent 2.5 million accountants employed in public practice, industry and commerce, government, and academia. Source: IFAC - International Federation of Accountants (2010) IPSASB's fact sheet. http://www.ifac.org/PublicSector/ [Accessed 7 February 2010].

44 IPSASB - International Public Sector Accounting Standards Board (2010) Proposed International Public Sector Accounting Standard Service Concession Arrangements: Grantor 
(New York: International Federation of Accountants (IFAC)). http://www.ifac.org/Guidance/EXD-Details.php?EDID=0134 [Accessed 7 March 2010]. 45 Government Business Enterprise (GBE) means an entity that has all the following characteristics (IPSAS 1.7):

(a) Is an entity with the power to contract in its own name;

(b) Has been assigned the financial and operational authority to carry on a business;

(c) Sells goods and services, in the normal course of its business, to other entities at a profit or full cost recovery;

(d) Is not reliant on continuing government funding to be a going concern (other than purchases of outputs at arm's length); and

(e) Is controlled by a public sector entity.

GBEs include both trading enterprises, such as utilities, and financial enterprises, such as financial institutions. GBEs are, in substance, no different from the entities conducting similar activities in the private sector. GBEs generally operate to make a profit, although some may have limited community service obligations under which they are required to provide some individuals and organisations in the community with goods and services at either no charge or at a significantly reduced charge (IPSAS 1.12).

46 IPSASB - International Public Sector Accounting Standards Board (2010) International Public Sector Accounting Standards (New York: International Federation of Accountants (IFAC)). http://web.ifac.org/publications/international-public-sector-accounting-standardsboard [Accessed 7 March 2010].

47 See Novak (2008a) for more information on the relationship between the Slovene Accounting Standards and IFRSs.

48 The IPSASB consists of 18 volunteer members from around the world with experience and expertise in public sector financial reporting. Members include practitioners from ministries of finance, government audit institutions, public practice and public members (who need not be members of the accounting profession). Members are appointed by the IFAC Board based on the recommendations from the IFAC Nominating Committee. The IPSASB follows a rigorous and transparent due process in the development of all IPSASs. This process provides the opportunity for all those interested in financial reporting in the public sector, including those preparers and users directly affected by the IPSASs, to make their views known to the IPSASB and ensure that those views are considered in the standards development process. Source: IFAC - International Federation of Accountants (2010) IPSASB's fact sheet. http://www.ifac.org/PublicSector/ [Accessed 7 February 2010].

49 See Alexander and Eberhartinger (2009), Alexander and Jermakowitz (2006) and Nobes (1993) for more about 'true and fair' view.

50 Source: IFAC - International Federation of Accountants (2010) IPSASB's fact sheet. http://www.ifac.org/PublicSector/ [Accessed 7 February 2010].

51 Governments that already apply full accrual accounting standards, and apply accounting standards that are broadly consistent with IPSAS requirements are: Australia, Canada, New Zealand, UK and USA. Source: IFAC - International Federation of Accountants (2007) IPSAS adoption by governments 2007. http://en.ifac.org/PublicSector/Downloads/IPSAS_Adoption_Governments.pdf [Accessed 7 March 2010]. 
A. Novak, M. Kokotec-Novak \& N. Halužan: Accounting Aspects of Reporting Business Relationships between Public Enterprises and Municipalities in Slovenia, Individual Comparisons with Italy and Austria, and International Guidelines

\section{References}

Alexander, D. \& Eberhartinger, E. (2009) The true and fair view in the European Union, European Accounting Review, 18(3), pp. 571-594.

Alexander, D. \& Jermakowicz, E. (2006) A true and fair view of the principles/rules debate, Abacus, 42(2), pp. 132-164.

Alexander, D. \& Nobes, C. (2001) Financial accounting: an international introduction (Harlow: Pearson Education).

Arnaboldi, M. \& Lapsley, I. (2009) On the application of accrual accounting: a study of conflict and ambiguity, European Accounting Review, 18(4), pp. 809-836.

Antunović, Ž., Cutvarić, M., Domazet, T., Mabić, S., Mlinarić, M. \& Vašiček D. (1994) Računovodstvo neprofitnih organizacija (Zagreb: Hrvatska zajednica računovodja i financijskih djelatnika, Sveučilišna tiskara).

Atkinson, A. A., Kaplan, R. S. \& Young, M.S. (2003) Management accounting, (Harlow: Pearson Education).

Barton, A. (2005) Professional accounting standards and the public sector - a missmatch, Abacus, 41(2), pp. 138-157.

Brezovnik, B. \& Oplotnik, Ž. (2003) Fiskalna decentralizacija v Sloveniji (Maribor: Inštitut za lokalno samoupravo in javna naročila).

Brezovnik, B. (2009) Topical Issues on the Legal Regulation of the Public Enterprise in Slovenia, Lex Localis - Journal of Local Self-Government, 7(2), pp. 182-183.

Carnegie, G. D. \& West, B. P. (2005) Making accounting accountable in the public sector, Critical Perspectives on Accounting, 16(7), pp. 905-928.

Cerkvenik, S. (2008) Lastniška razmerja $\mathrm{v}$ zuez̨i z javno infrastrukturo $\mathrm{v}$ državah Evropske unije (Ljubljana: LM Veritas).

Christensen, M. (2005) The »third hand«: private sector consultants in public sector accounting change, European Accounting Review, 14(3), pp. 447-474.

Christiaens, J. (2004) Capital assets in governmental accounting reforms: comparing Flemish technical issues with international standards, European Accounting Review, 13(4), pp. 743-770.

Čižman, M. (2009) Letna poročila določenih uporabnikov enotnega kontnega načrta, IKS, 3/09, pp. 7-10.

Duhovnik, M.( 2006) Ekonomski in računovodski vidik iqvajanja gospodarske javne službe na podlagi pogodbe o finančnem najemu infrastructure (Ljubljana: LM Veritas).

Ferfila, B., Kovač,P., Žurga, G., Klinar, I., \& Plaznik, A. (2002) Ekonomski vidiki javne uprave (Ljubljana: Fakulteta za družbene vede).

Grafenauer, B. (2009) An analysis of the provision of local public utility services by way of illustration of two Slovenian municipalities, Lex Localis - Journal of Local Self-Government, 7(2), pp. 209-219.

Hansen, W. (2004) Qualität hat ihren Preis! - Aber welchen? Zukunft der Wasserversorgung und Abwasserbeseitigung. http://ecologic.eu/de/1306.

Halužan, N. (2009) Poslovni in davčni vidik amortizacije na področju poslovanja komunalnih javnih podjetij (Maribor: Ekonomsko-poslovna fakulteta).

Halužan, N. (2009) Računovodski vidik amortizacije javnih podjetij (Maribor: Društvo računovodij, finančnikov in revizorjev).

Hauth, E. (2009) Aktuelle Regeln und Anwendungen des Haushaltswesens in den Bundesländern: Eine kritische Analyse, Studie im Auftrag des Staatsschuldenausschusses, avaliable at http://www.staatsschultenausschuss.at, 19.11.2009.

Higson, A. (2003) Corporate financial reporting - theory \& practice (London: SAGE Publications). 
Hood, C (1995) The »new public management« in 1980s: variations on a theme, Accounting, Organisations and Society, 20(2/3), pp. 93-109.

Humprey, C. (2005) The questionable nature of »third hand« public sector accounting solutions: a case for change?, European Accounting Review, 14(3), pp. 475-485.

Inštitut za raziskave v energetiki, ekologiji in tehnologiji, (2008) Pregled in analiza stanja na področju oskerbe s pitno vodo (Ljubljana: Gospodarska zbornica Slovenije - Zbornica komunalnega gospodarstva).

Jackson, A. \& Lapsley, I. (2003) The diffusion of accounting practices in the new »managerial« public sector, International Journal of Public Sector Management, 16(5), pp. 359-372.

Jereb, S. \& Petrovič, J. K. (2008) Računovodsko evidentiranje različnih oblik javno-zasebnih partnerstev, Revizor, 19(6), pp. 23-41.

Kieso, D. E., Weygandt J. J., Warfield, T. D. (2005) Intermediate accounting, 11th edition (New York: John Wiley \& Sons, Inc).

Kokotec-Novak, M. (1998) Nekatere značilnosti računovodske obravnave nepridobitnih organizacij glede na strokovne opredelitve $\mathrm{v}$ tujini (Portorož: Zveza računovodij, finančnikov in revizorjev Slovenije).

Kokotec-Novak, M. (2001) Rechnungslegung der Nonprofit-Organisationen in der Republik Slowenien, Österreichische Zeitschrift für Rechnungswesen, 8(1), pp. 245.

Kranjc, V. (2009) EU and International Organisations Rules on Public-Private Partnerships, Lex localis - Journal of Local Self-Government, 7(2), pp. 197-207.

Lapesly, I., Mussari, R. \& Paulsson, G. (2009) On the adoption of accrual accounting in the public sector: a self-evident and problematic reform, European Accounting Review, 18(4), pp. 719-723.

Liang, P. J. (2001). Recognition: an information content perspective. Accounting Horizons, 15(3), pp. $223-242$.

Lozej, M. (2006) Ekonomski in računovodski vidik įvajanja gospodarske javne službe na podlagi pogodbe o poslovnem najemu infrastrukture (Ljubljana: LM Veritas).

Lüder, K. \& Jones, R. (2003) 'The diffusion of accrual accounting and budgeting in European governments - a cross-country analysis', In: Lüder, K. and Jones, R. (Eds.) Reforming Governmental Accounting and Budgeting in Europe, pp. 1-45 (Frankfurt: Fachverlag Moderne Wirtschaft).

Nobes, C. (1993) The true and fair requirement: impact on and of the Fourth Directive, Accounting and Business Research, 24(93), pp. 35-48.

Novak, A. (2007) Vrednotenje gospodarskib kategorij pri zunanjem računovodskem poročanju (Koper: Fakulteta za management).

Novak, A. (2008) 'Harmonization of Slovenian accounting standards with International Financial Reporting Standards', In: Kandžija, V. \& Kumar, A. (eds.), 50 years of European Union: research monograph, pp. 511-520 (Rijeka: Faculty of Economics).

Novak, A. (2008) Sources of influence on accounting information. In: Jozefcyk, J., Thomas, W. \& Turowska, M. (eds). Congress proceedings. [Compact disc ed.]. (Wrocław: Oficyna Wydawnicza Politechniki Wrocławskiej), pp. 530-539.

Obermann, G. \& Soukup, K. (1992) Öffentliche Unternehmen und die europäische Integration (Wien: Manzsche Verlags-und Univeristäthandlung).

Oplotnik, Z. \& Brezovnik, B. (2004) Financing local government in Slovenia, Post-Communist Economies, 16(4), pp. 483-496.

Pina, V., Torres, L. \& Yetano, A. (2009) Accrual accounting in EU local government: one method, several approaches, European Accounting Review, 18(4), pp. 765-807.

Rau, T. (1994) Betriebswirtschaftslehre für Städte und Gemeinden (München: Verlag Vahlen). 
A. Novak, M. Kokotec-Novak \& N. Halužan: Accounting Aspects of Reporting Business Relationships between Public Enterprises and Municipalities in Slovenia, Individual Comparisons with Italy and Austria, and International Guidelines

Raiborn, C. A. \& Watson, S. F. (2003) Core concepts of accounting (Hoboken: John Wiley \& Sons, Inc).

Roberts, C., Weetman P. \& Gordon P. (2002) International financial accounting (Harlow: Pearson Education).

Setnikar Cankar, S., Klun, M., Aristovnik, A. \& Pevcin P. (2008) Ekonomika javnega sektorja (Ljubljana: Fakulteta za upravo).

Seidel, H. \& Temmen, R. (2007) Grundlagen der Volkswirtschaftslehre (München: Oldenbourg Verlag).

Sturm, F. (2009) Kärntner Allgemeine Gemeindeordnung, Kommentierte Gesetzeausgabe, (Klagenfurt: Verlag Kärntner Druck-und Verlagsgesellschaft).

Sturm, F. ( 2003) Kärntner Gemeindehaushaltsordnung, 2. Aktualisierte Auflage, (Klagenfurt: Kärtner Druck-und Verlagsgesellschaft).

Thom, N. \& Ritz, A. (2006) Public Management, Innovative Konzepte zur Fübrung im öffentlichen Sektor (Wiesbaden: Gabler Verlag).

Turk, I., Kavčič, S., Kokotec-Novak M., Koželj S. \& Odar M. (2004) Finančno računovodstvo (Ljubljana: Slovenski inštitut za revizijo).

Van Hulle, K. (2004) From Accounting Directives to International Accounting Standards. In: Leuz, C., Pfaff, D. \& Hopwood, A. (eds.) The Economics and Politics of Accounting, pp. 349375, (Oxford: Oxford University Press).

Werner, J., Röber, M. \& Wollmann, H. (2006) Public Management - Grundlagen, Wirkungen und Kritik (Berlin: Sigma).

Weygandt, J. J., Kieso, D. E. \& Kimmel P. D. (2008) Principles of financial accounting, 9th edition (New York: Aspen).

Wilson, E. \& Kattelus S. (2004) Accounting for Governmental and Non-profit Entities (New York: McGraw Hill).

Zimmerman, H. (1999) Kommunalfinanzen (Baden-Baden: Nomos). 